\title{
Comparison of recovered carp scales (Cyprinus carpio) gelatin and commercial calf and pork skin gelatins
}

\section{Sazan pulu (Cyprinus carpio) kullanılarak elde edilen jelatin ve ticari dana ve domuz derisi jelatinlerinin kıyaslanması}

\author{
Mehmet Tolga Dinçer ${ }^{*}$ Ömer Alper Erdem • Hülya Kalkan • Mehmet Çağıl Üçok
}

Ege University, Faculty of Fisheries, Department of Fishery and Processing Technology, 35100, Bornova - Izmir

*Corresponding author: tolga.dincer@ege.edu.tr

Received date: 13.07 .2016

Accepted date: 07.09.2016

How to cite this paper:

How to cite this paper:
Dinçer, M.T., Erdem, Ö.A., Kalkan, H. \& Üçok, M.Ç. (2016). Comparison of recovered carp scales (Cyprinus carpio) gelatin and commercial calf and pork skin gelatins. Ege Journal of Fisheries and Aquatic Sciences, 33(4): 335-341. doi: 10.12714/egejfas.2016.33.4.05

\begin{abstract}
Significant progress carries some evaluations towards the developments on seafood processing technologies and waste utilizing sector in recent years. Evaluation of wastes also has the potential to provide raw material for many industrial sectors. Evaluating the wastes also has a real potential for many industry sectors to obtain raw materials. The development of new products and commercially important of bio-molecules which have to be obtained from the wastes were important area for researches. Gelatin is used as a raw material for food industry and other industries, not only in our country but also in the world. Because of the growing demand particularly in Muslim countries hesitant considering alternatives to pork and calf sourced products are required. In the current study collagen which is used as raw material for many industries was recovered from carp scales (Cyprinus carpio). Obtained collagen was also used to produce gelatin product and some physical (colour, odour) and some functional (gelling temperature, viscosity, gel strength) properties were compared with commercial calf and pork skin gelatins.
\end{abstract}

Keywords: Gelatin, electronic noise, collagen, carp, bloom value

Öz: Son yıllarda gelişen teknoloji ve işleme sektöründeki gelişmeler işleme atıklarının değerlendirilmesi yönünde kayda değer gelişmeleri beraberinde getirmiştir. Atıkların değerlendirilmesi, aynı zamanda birçok sanayi sektörüne hammadde sağlayacak potansiyele sahiptir. Yeni ürünlerin geliştirilmesi ve ticari öneme sahip olan biyo-moleküllerin su ürünleri artıklarından elde edilmeleri araştırma için önemli bir alandır. Jelatin gerek dünyada, gerek ise ülkemizde gıda endüstrisi ve diğer endüstriler tarafından kullanılan bir hammaddedir. Artan talep karşısında ve bilhassa Müslüman ülkelerdeki tereddüt dikkate alındığında domuz ve dana kaynaklı üretime alternatifler aranmaktadır. Bu çalışmada, endüstriyel anlamda birçok sanayi sektöründe hammadde olarak kullanılan kollajen maddesi, sazan balığı (Cyprinus carpio) pullarından elde edilmiştir. Elde edilen kollajenin jelatin üretiminde kullanılması gerçekleştirilmiş ve bazı fiziksel özellikleri (renk, koku) ve bazı fonksiyonel özellikleri (jelleşme sıcaklığı, viskozitesi, jel dayanım değeri) ticari dana ve domuz derisi jelatini ile karşılaştırımışır.

Anahtar kelimeler: Jelatin, elektronik burun, kollajen, sazan, bloom değeri

\section{INTRODUCTION}

Total production of gelatin was nearly 326000 metric tons in the world. $46 \%$ of the total gelatin recovered from pigskin, $29.4 \%$ from bovine, $23.1 \%$ from bones and $1.5 \%$ from other parts of the ground animals (Gómez-Guillén et al., 2002). "Gelatin" term is used for food products which were obtained from not only bones and skins of ground animals but also derived from cold blooded animals like fish by using hydrolysis techniques (Norland, 1990, Osborn et al., 1990, Grossman and Bergman, 1992, Gudmundsson and Hafsteinsson, 1997). Collagen proteins which are also known as connective tissue proteins are the source of gelatin product. By using a thermal treatment these collagen proteins can easily denaturated and converted to a gelatin (Bailey and Paul, 1998). Formed gelatin has an irreversible structure and can dissolve in water.
Destruction of primary, secondary and tertiary bounds of native collagens from animals is the source of gelatin. But gelatin structure form could not be reverse again in to collagen (Fernandez-Diaz et al., 2001). Gelatin can be obtained with the partial hydrolysis of collagen which was derived from the skin, white connective tissue and also bones of animals (Morrison et al., 1999). On the other hand also can be obtained from fish skin and scale. In last decade obtained gelatins from fish became an alternative which is acceptable for halal (Muslim) and kosher (Jewish) products, these extractions have been reported previously for different fish species in the literature. The recent improvements in fish processing technology enable the converting of fish processing by-products into new valueadded products or biomolecules. These motion carried the 
researches to a commercially and important platform. Nearly $25 \%$ of the global fishery and processing productions are discarded as waste or processed into fish oil, fishmeal or pet food (Kim and Mendis, 2006). Most popular gelatins in the commercial sector are bovine and porcine gelatins; $60 \%$ of the market consists of these products. Due to the cultural and religious point of view consumers has some doubts and skepticism on these products. Also some part of the consumers has some health related concerns (Karim and Bhat, 2009). The utilization of aquatic resources accounts from the total was just $1 \%$ of total gelatin production (GME, 2013). And almost the origin of the gelatin obtained from the aquatic resources comes from mostly the fish intestine and fish skin (Liu et al., 2007). In 2013, the Turkish Statistical Organization (TUIK, 2013) estimated that 8267 tons of inland water catches come from carp (Cyprinus carpio) in Turkey. Just from this amount carp 165 tons of dry scale can be provided in Turkey. In a simple calculation this means that 49 tons dry gelatin and 705 tons of gel can be produced $(6,67 \% \mathrm{w} / \mathrm{v})$. The most expensive and important step in collagen recovery is removing lipid process (alchol treatment), not only in calf and pork gelatins but also fishy odour can be a problem for consumption (Sae-leaw and Benjakul, 2014). To beter understand the odour effects electronic noise was used to monitor odours in the current study.

Electronic nose is a device which has a sensor array and can measure sensitively in the degree that man could not sense (Saraoğlu, 2008). Electronic noise equipment can be used as a quality analyzer for gas mixtures in food industry. With using this equipment cheaper techniques can be developed when compared with other techniques (El Barbri et al., 2009). Sensors type with different characteristics such as electrochemical (metal oxide semiconductor, MOSFET), optical or piezoelectric sensors (quartz crystal, surface acoustic wave) are used widely (James et al., 2005). QCM gas sensors already used in many industrial areas and almost in food industry (Escuderas et al., 2011). The working style of sensors depends on frequency (frequency shift) and the proportional mass of material deposited upon the crystal (James et al., 2005). Little studies on electronic nose for gelatin odour can be seen in the literature (Muyonga et al., 2004; Ninan et al., 2014; Shyni et al., 2014). In the current study collagen was extracted from carp scales (Cyprinus carpio) and obtained collagen was used to produce gelatin product. Some physical properties like colour, odour, and some quality properties like gel strength, viscosity and gelling temperature were compared with commercial calf and pork gelatin.

\section{MATERIAL AND METHODS}

\section{Fish scale preparation}

Scales of carp (Cyprinus carpio) with an average body weight of $500-800 \mathrm{~g}$ were provided from Tan Su Ürünleri Ltd. Company in Bornova, Izmir. The scales of carp were removed by hand, one by one, samples were packaged in polyethylene bags. After filling with ice samples were quickly transported to the laboratory. Consequently, scales washed and dried by placing a table with using air condition flow. 1200 grams of scale was taken for collagen extraction and gelatin recovery.

\section{Gelatin extraction}

The extraction method was chosen to extract Type 1 collagens which were based on to obtain collagen proteins from the scales. Method was the combination of 3 important steps which were separation of non-collagen proteins, removing lipids from the scales and de-mineralization process. In the deproteinization step; $5 \% \mathrm{NaCl}$ solution $(1 / 10, \mathrm{w} / \mathrm{v})$ and $0.4 \%$ $\mathrm{NaOH}(1 / 10, \mathrm{w} / \mathrm{v})$ were used, respectively. 1200 grams of dried scales were stirred for $30 \mathrm{~min}$ in room temperature with $5 \% \mathrm{NaCl}$ solution two times. After washing scales $0.4 \% \mathrm{NaOH}$ $(1 / 10, w / v)$ solution was used to remove the non-collagenous proteins during $60 \mathrm{~min} .10 \%$ Isobutyl alcohol $(1 / 4, \mathrm{w} / \mathrm{v})$ to remove lipids from the scales. This lipid removing step was repeated three times for thirty min in a digital linear shaker (Dragon Lab SK - 330 model, Beijing, China). As a final step demineralization with $0.5 \mathrm{~N}$ (again use \%) EDTA solutions at an inherent $\mathrm{pH} 7.66$ at was performed with four different time periods; 12 h, 2 h, 2 h and $1 \mathrm{~h}$ (Dragon Lab SK - 330 model, Beijing, China) shaking. Between all steps, scales were collected by filtering through a sieve and washed with distilled water to separate any residual matter. Collected scales were soaked in $0.05 \mathrm{M}$ acetic acid solution for $3 \mathrm{~h}$. Filtered scales were placed in a tray and $1 / 3(\mathrm{w} / \mathrm{v})$ water was added and heated at $60^{\circ} \mathrm{C}$ overnight in an oven. After filtering taken filtrate (dried thin films) was placed in a plastic tray and dried at room temperature using air condition overnight (set on $18{ }^{\circ} \mathrm{C}$, flow temperature was determined $10 \pm 2^{\circ} \mathrm{C}$ ). To perform the gelatin powder, dried thin films were ground using a coffee grinder. The yield of gelatin from the fish scales was calculated on a dry weight basis and expressed in \%.

\section{Calf and pork skin gelatins}

Calf skin gelatin (Gelita GA, Germany, $1 \mathrm{~kg}$ packs, leaves) samples were purchased from food ingredients provider company in Turkey. Because of the Turkish Laws porks products cannot be imported so same company's commercial pork gelatin product (Gelita GA, Germany,1 kg packs, leaves) were purchased from super market chain in Hamburg, Germany.

\section{Proximate composition}

The moisture content (oven - drying procedure), ash content, crude protein and fat contents of samples were performed using the AOAC official methods 934. 01, 942. 01, 954.01 and 991.36 respectively (AOAC, 2000).

\section{Determination of gel strength}

GMAI (2012) standard method was used to determine the bloom strength of gelatins.

Samples were weighed and filled into the bloom bottles then dissolved inside of distilled water $\left(55^{\circ} \mathrm{C}\right)$ to perform the final concentration of $6,67 \%(w / v)$. After keeping in the 
refrigerator during 16 hours at $5^{\circ} \mathrm{C}$ gels were performed. Bloom strength was determined using a TAXT plus Texture analyzer (Stable Micro Systems, Godalming, UK), $25 \mathrm{~kg}$ load cell and 1. $27 \mathrm{~cm}$ diameter (GL 4/P 05S) probe was used. The maximum force (in grams) recorded when the probe had penetrated $4 \mathrm{~mm}$ into gelatin gel's from surface.

\section{Determination of viscosity}

Viscosity values of the gelatins were determined by using the method of Zhou and Regenstein (2004). Viscosity values of the gelatins were analyzed by using Brookfield DV + II Pro viscometer (Middleboro, USA). Gell solution was $(6.67 \% \mathrm{w} / \mathrm{v})$ prepared at $55^{\circ} \mathrm{C}$ for 30 min in the magnetic stirrer until completely dissolved. HA - 4 spindle was used by using helipad stand at $25^{\circ} \mathrm{C}$ in $60 \mathrm{rpm}$. With the help of helipad stand data were taken from vertical parts of the $100 \mathrm{ml}$ gel solution.

\section{Gelling temperature}

Gelling temperature of the gelatins were determined by a modified (modified by Dincer et al., 2013) method of Zhou and Regenstein (2004). Brookfield DV + II Pro viscometer (Middleboro, USA in $60 \mathrm{rpm}$ with using HA - 4 spindle and helipad stand with taking the data on $60 \mathrm{rpm}$ in each minute (continues test was performed until the spindle stop) was used to determine the gelling point (temperature). Data was taken between $50^{\circ} \mathrm{C}$ and $4^{\circ} \mathrm{C}$ from the $100 \mathrm{ml}$ gelatin gel solution solution. Cooling was supported after reaching the room temperature with covering the sample container crashed ice. Gelling point was recorded after the spindle reached the maximum viscosity and stopped.

\section{Colour measurements}

Colour measurements were taken by using method of Dincer et al., (2013). Color measurement was performed by using $6,67 \%(w / v)$ gelatin gels. Dissolved gelatin content transferred to a plastic container box and then placing in the refrigerator for 16 hours at $5^{\circ} \mathrm{C}$. Gel blocks were performed, procedure was used for each sample to have same smooth surface and same thickness. Preliminary measurements were taken from the surface of calibration kits to record the blind. Then gel blocks were put in to the calibration kits for measurements. Because of the transparent structure measurements were taken over standard calibration kits (Tile white and Tile black). And after calculations reference blind values were subtracted from the taken value from gel blocks.

Used calibration kit were LZM 256- Tile white $(x=14.8$, $Y=21.2 ., Z=13.9)$ and Tile Black $(x=14.5, Y=20.8, Z=15.0)$. By using this technique constancy was performed in measurement. Data were recorded due to the CIE Lab system, $L^{*}$ value which denoted lightness with a scale between 0 to 100 (black to white), $a^{*}$ value denoted $(+)$ red or $(-)$ green; and $b^{*}$ values denoted $(+)$ yellow or $(-)$ blue values were determined.

\section{Electronic Noise measurements}

For the E-noise measurements 2 different measurements were performed. For the first measurements gels were heated up to $55^{\circ} \mathrm{C}$ and then placed in to container while they were hot. And for the second measurement gels were removed from refrigerator and waited until they become in room temperature. While waiting covers of the flasks were close.

Electronic nose device used in the current study was developed by TUBITAK Marmara Research Center. Electronic nose system was the combination of; a sensor array, a A/D converter, a computer. Also pc includes software for monitoring responses $(\mathrm{Hz})$ of electronic nose and for performing principal component analysis. For the sensor array, fourteen quartz crystal microbalance sensors were used due to method of Mumyakmaz et al., (2008). All gelatin samples were analyzed by two ways with the equipment. Both measurements were done in room temperature. Electronic nose measurement was performed during 60 seconds for each sample. These processes were repeated five times. The data from responses of electronic nose was processed with principal component analysis (PCA) with using software.

\section{Statistical analysis}

Statistical analysis were performed by using SPSS e and means comparison were done with using ANOVA test using Duncan's multiple range tests between gelatin values.

\section{RESULTS AND DISCUSSION}

\section{Proximate composition and yield of products}

The proximate composition values of carp scales gelatin were determined as follows (dried form); $4.73 \pm 0.03 \%$ moisture, $0.01 \pm 0.01 \%$ ash, $0.01 \pm 0.00 \%$ carbohydrate and $95.05 \pm 1.0 \%$ protein and no fat was determined. Total yield of gelatin was calculated as $28.18 \%$ (338.16 grams of dried gelatin recovered from $1200 \mathrm{~g}$ dry carp scales). The amount of protein in gelatin was determined respectively; 95 (carp scale), 91 (Calf skin) and 86 (Pork skin) percents in the current study. This result was found to be higher when carp scale gelatin was compared with Amur sturgeon skin gelatin $90.4 \%$ and Nile tilapia skin gelatin $88.5 \%$ (Zeng et al., 2010). Rahman et al., (2008) reported the protein content of bovine and pork gelatin as $88.7 \%$ and $90.65 \%$ respectively. But in the current commercial pork skin gelatin's protein content was found to be lower than the mentioned study (Table 1.). As an inverse of this founding calf skin gelatin protein content was found higher with the value of $91 \%$. The differences of the moisture contents were remarkable. Determined moisture values can be given as follows; $4.73 \%$ (carp scale), $7.13 \%$ (Calf skin) and $9.23 \%$ (pork skin) although all the gelatins form were in dried leaves. On the other hand no fat content was determined in fish scale gelatin whereas for calf and pork gelatin fat values were 1\% (Table 1).

\section{Gel strength (Bloom value) and viscosity values}

In the current study carp scale gelatin which was produced by using acidic technique, gave us high bloom values. Taken results show that carp scale gelatin bloom value is statistically same with the calf skin gelatin bloom value and significantly higher than commercial pork gelatin (Table 2) 
Table 1. Proximate chemical composition comparison of gelatins

\begin{tabular}{lllccc}
\hline \multicolumn{1}{c}{ Samples } & Protein & Moisture & Crude fat & Crude ash & \multicolumn{2}{c}{ Carbohydrate } \\
& $(\%)$ & $(\%)$ & $(\%)$ & $(\%)$ & $(\%)$ \\
\hline Carp scale gelatin & $95.05 \pm 1.0^{\mathrm{a}}$ & $4.73 \pm 0.03^{\mathrm{a}}$ & $0.00 \pm 0.00^{\mathrm{a}}$ & $0.01 \pm 0.01^{\mathrm{a}}$ & $0.01 \pm 0.00^{\mathrm{a}}$ \\
Calf skin gelatin & $91.03 \pm 0.2^{\mathrm{b}}$ & $7.13 \pm 0.03^{\mathrm{b}}$ & $1.12 \pm 0.12^{\mathrm{b}}$ & $0.02 \pm 0.01^{\mathrm{a}}$ & $0.01 \pm 0.00^{\mathrm{a}}$ \\
Pork skin gelatin & $86.45 \pm 0.4^{\mathrm{c}}$ & $9.23 \pm 0.02^{\mathrm{c}}$ & $1.00 \pm 0.05^{\mathrm{b}}$ & $0.00 \pm 0.00^{\mathrm{a}}$ & $0.00 \pm 0.01^{\mathrm{a}}$
\end{tabular}

Arithmetic means and standard deviation. $n=3$, different superscript letters in the same column denotes statistical difference $(P<0.05)$

Table 2. Gel strength (Bloom value) and viscosity comparison between gelatins

\begin{tabular}{llll}
\hline Properties & Carp scale gelatin & Calf skin gelatin & Pork skin gelatin \\
\hline Gel strength (g) & $341.87 \pm 0.12^{\mathrm{a}}$ & $336.87 \pm 5.99^{\mathrm{a}}$ & $308.07 \pm 4.1^{\mathrm{b}}$ \\
Viscosity (cP) & $26.3 \pm 0.1^{\mathrm{a}}$ & $26.7 \pm 0.2^{\mathrm{a}}$ & $6.67 \pm 0.01^{\mathrm{b}}$ \\
\hline
\end{tabular}

Arithmetic means and standard deviation. $G S n=10, V s n=3$, Different superscript letters in the same rows denotes statistical difference $(P<0.05)$

Bloom value (gel strength) is the most important quality criteria for gelatins. Sector and the industry prefer and expect reasonably high bloom value products (Zhou and Regenstein, 2004). In the current study gel strength of the products varied between 308 and $341 \mathrm{~g}$ and viscosity values varied between 26,3 and $6.67 \mathrm{cP}$ (Table 2). Unexpected result was seen in pork samples; very low viscosity value was determined (Table 2) although the gel strength of the sample was over $300 \mathrm{~g}$ that might be due to reason of some impurities. High molecular weights of non-collagen protein fractions, in the samples may decrease viscosity but not the gel strength. Also in previous studies positive correlations of gel strength and viscosity (Boran and Regenstein, 2009; Zhou and Regenstein, 2004) can be seen. Statistical analysis showed that the pork gelatin sample was significantly lower and different from other in terms of bloom value and viscosity $(P<0.05)$. The lowest viscosity of gelatin extracted from pork skin was the lowest among the calf skin gelatin and carp scale gelatin samples. This results suggesting that carp scale can be used as an alternative raw material for gelatin production, with carrying the advantage of high viscosity and high bloom value in last gelatin product.

\section{Gelling temperature}

The gelling temperature values of the samples are given in Figure 1, Figure 2 and Figure 3 and the plots of delta (viscosity -temperature) was compared with temperature $\left({ }^{\circ} \mathrm{C}\right)$ can be seen in these figures, respectively. Gelling temperature of carp scale, pork skin, and calf skin gelatins were close to each other and due to the results suitable for foods in refrigerator conditions. In figures relatively sharp increase in delta can be seen. At the summit of the delta max viscosity value can be seen in correlation with decreasing in temperature, and phase change for each sample when become $0 \mathrm{cp}$ viscosity. The lowest gelling temperature was measured as $9.1^{\circ} \mathrm{C}$ in pork skin gels that value was lower than the value of $10.5^{\circ} \mathrm{C}$ reported for porcine skin gelatin gels by Kasankala et al., (2007). The highest gelling temperature was $13.4^{\circ} \mathrm{C}$ for calf skin samples, these results show that carp scale gelatin with its $10.6^{\circ} \mathrm{C}$ gelling point might be useful for particular food applications that require gelling temperatures like other gelatins. Supporting similar results can also be seen in the study of Boran et al., (2010).

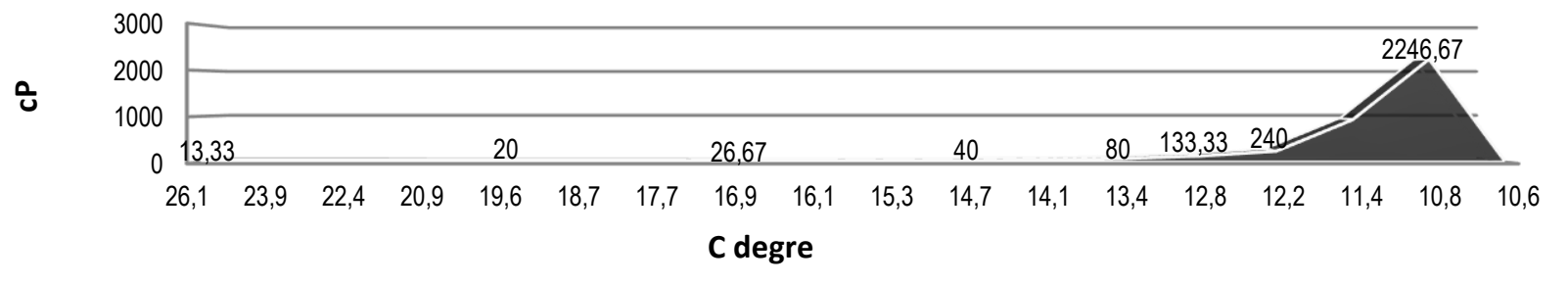

Figure 1. Carp scale gelatin gelling temperature 


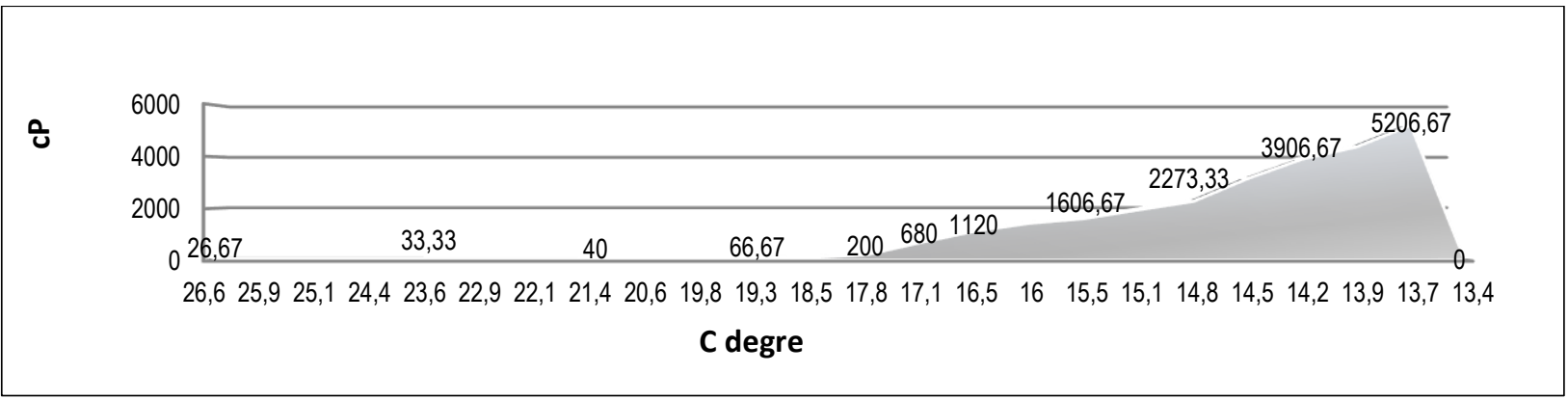

Figure 2. Calf skin gelatin gelling temperature

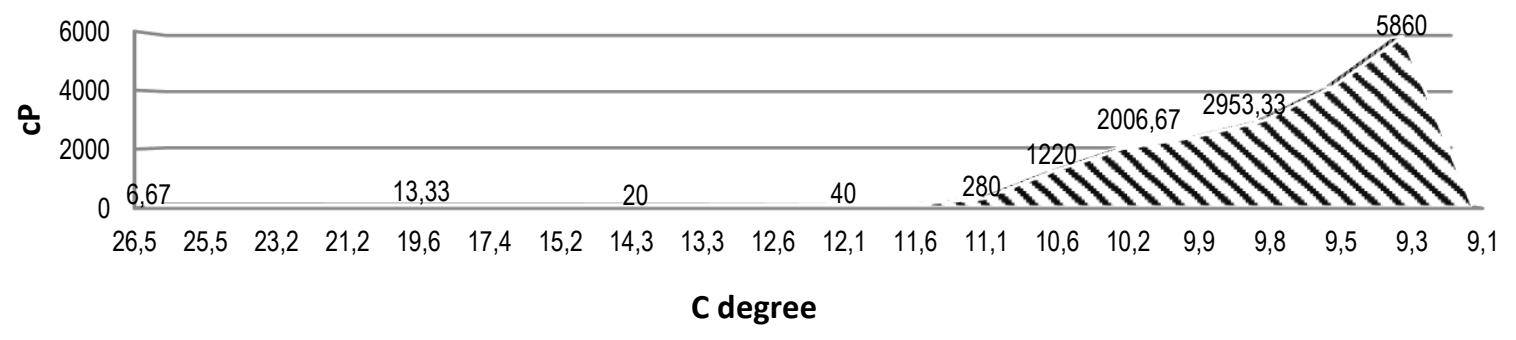

\section{Figure 3. Pork skin gelatin gelling temperature}

\section{Colour measurements values}

As mentioned in material section two different reference kits were used as a base in color measurements $(\mathrm{B} \& \mathrm{~W})$ because of the transparency of the gels. Figure 4 denotes the results of White tile values. Due to the taken results gelatins $L^{*}$ (Lightness) values were determined as follows, respectively; Carp scale $(35,80 \pm 0,51)$, Calf skin $(28,17 \pm 0,27)$ and pork skin $(26,78 \pm 0,56)$. Due to the taken data carp scale gelatin $L^{*}$ value were determined significantly higher than other commercial gelatin samples. Same result can also be seen in Black tile measurement (Figure 5) of which results were respectively; $34,77 \pm 0,43,27,56 \pm 0,70$ and $27,04 \pm 0,45$ for $L^{*}$.

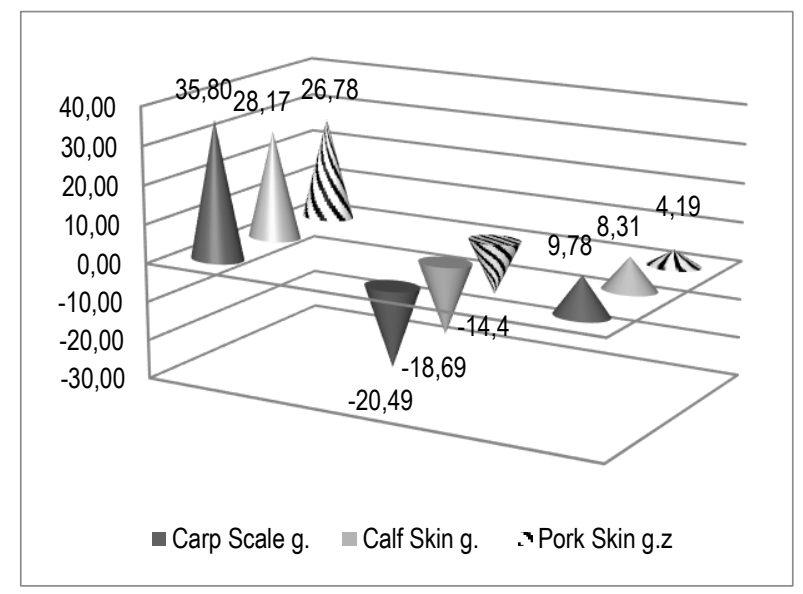

Figure 4. Colour measurement results over Tile White $(x=14.8$, $Y=21.2 ., Z=13.9)$
In Figures 4 and 5 as can be seen in $a^{*}$ parameters of color attributes no statistically difference were determined between samples $(P>0.05)$. But in $b^{*}$ attributes pork skin gelatin values were significantly lower $(P<0.05)$ than Carp scale and calf skin gelatins. Although the carp scale and calf skin were similar, $a^{*}$ values of carp scale showed color characteristic typical of fish gelatins, where the color tended to a little bit yellow. The $L^{*}$ parameter of carp scale was significantly higher than others, suggesting that carp scale gelatin was lighter than calf skin and pork skin gelatins. The difference in color among gelatins may occur due to the presence of pigment inherent in the material and depends on the raw material (Jongjareonrak et al., 2010).

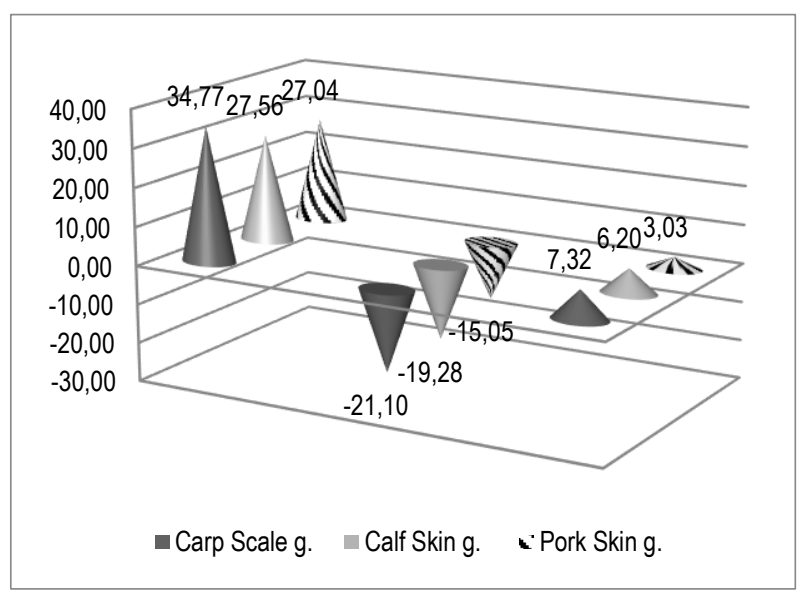

Figure 5. Colour measurement results over Tile Black ( $x=14.5$, $Y=20.8, Z=15.0$ ) 


\section{Electronic Noise Values}

According to the taken data due to the PCA technique (Kent et al., 2004), first principal component was determined $93 \%$ and second principal component was determined 5 . Total $98 \%$ of responses from the sensors was detected. This covariance matrix of PCA was taken from multi sensor equipment showed ud $98 \%$ of the responses detected. Results of the samples according to room temperature and the $55^{\circ} \mathrm{C}$ responses can be seen in Figure 6 . To determine the differences between the odour of the gelatin gells in $55^{\circ} \mathrm{C}$, measurement was performed. Due to the taken data as shown in Figure 6. No significant difference was determined. These heated gel forms gave us very similar results. Thus explain that gelatins originated from calf skin, pork skin and carp scale smells very similar when in liquid gel forms in $55^{\circ} \mathrm{C}$. As known increasing in temperature may increase the molecule speeds. Absolutely these gas molecules can easily be taken by the pumps of the E-noise but sensors could not be response easily because of the speed of odour molecules. In the literature odour comparison of the gelatins were performed by using sensorial methods instead of E-noise. In the study of Muyonga et al
(2004), sensorial results did not showed a significant difference in odour between obtained Nile perch gelatin and bovine bone or commercial fish gelatins studied. Previously mentioned statement about heat and molecules may explain the reasons of no difference.

For the second measurements gells were placed in to the container while they were in room temperatures. Cover of the flasks removed before placing in to the container of E-noise immediately. During the measurement both samples and the atmosphere inside of the container were equal. The responses of electronic noise measurement for calf skin, pork skin and carp scale gelatins were all determined different (Fig 6.). Similar results can also be found by Ninan et al., (2014). Although they used a sensorial method by the panelists, the odour scores were significantly higher $(P<0.05)$ for bovine and porcine skin gelatins than carp skin gelatins. In another study, Choi and Regenstein (2000) observed that fish gelatins had less off odour and better aroma than pork gelatins on sensory evaluation. Due to the taken results it can be concluded that both gels gave us different results depends on their origin.

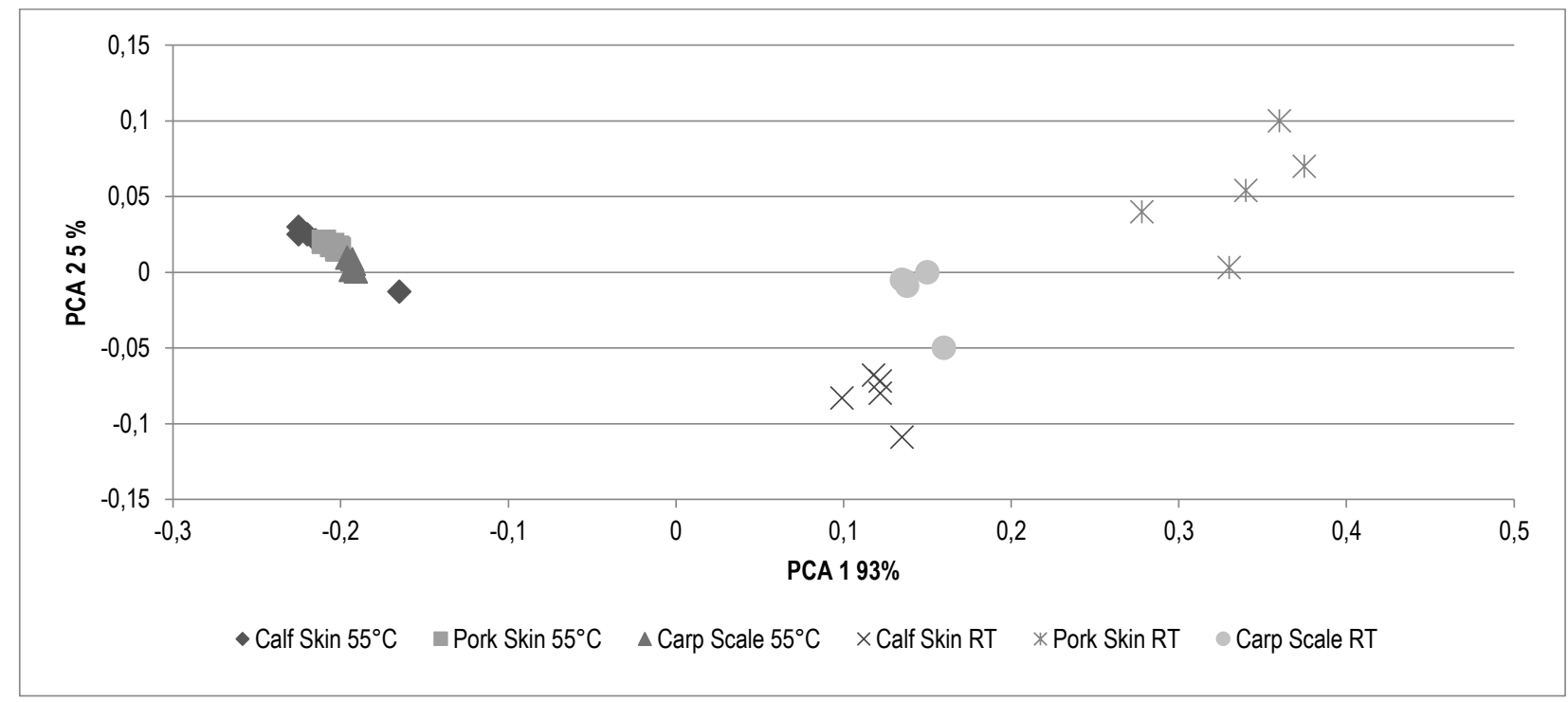

Figure 6. E-noise measurement results of samples in $55^{\circ} \mathrm{C}$ and room temperature

\section{CONCLUSION}

In the current study obtained gelatin from carp scale was compared with two different commercial gelatin products. Taken data showed that carp scale might be successfully used as a raw material for gelatin production with an advantage of; high gel strength, viscosity, gelling temperatures, odor and color properties. Many of the functional and quality characteristics results were determined similar with calf skin and pork skin gelatins. Also advantage of the potential halal certificate may increase the marketing potential of the product. With these advantages carp scale gelatin may open to new marketing areas in Islamic and Jewish countries without any doubts of consumers. For future studies researchers should focus on decreasing the production costs. Current study designed and realized in lab conditions and many analytical degree chemicals were used. And calculated expenses showed that prices of the product were higher than commercial pork and calf skin gelatins. These expenses should decrease in future studies by using alternative chemicals, and the design of the production line should be modified for industry.

\section{ACKNOWLEDGEMENTS}

Carp scale gelatin part of this study was supported by project: 2014/SUF/021 and some results of the study were presented as a poster presentation in SUSEMP 2015 Symposium, 1-4 September 2015. 


\section{REFERENCES}

AOAC. (2000). Official Methods of Analysis 16th edn"., Association of Official Analytical Chemists, Arlington, USA

Bailey, A.J \& Paul, R.G. (1998). Collagen - A not so simple protein. JournalSociety of Leather Technologists and Chemists, 82 (3): 104-110.

Boran, G., Mulvaney, M.S. \& Regenstein, J.M. (2010). Rheological properties of gelatin from silver carp skin compared to commercially available gelatins from different sources. Journal of Food Sciences, 75(8): 565-571. doi: 10.1111/j.1750-3841.2010.01543.x

Boran, G. \& Regenstein, J.M. (2009). Optimization of gelatin extraction from silver carp skin. Journal of Food Science, 74(8): 432-441. doi: 10.1111/j.1750-3841.2009.01328.x

Choi S.S. \& Regenstein J.M. (2000). Physicochemical and sensory characteristics of fish gelatin. Journal Food Science, 65:194-199.

Dincer, T., Akagündüz, Ö.Y. \& Sargın, H. (2013). Levrek (Dicentrarchus labrax) Pullarından Jelatin Üretimi ve Jelatinin Bazı Fonksiyonel Özelliklerinin Tespiti. Tubitak Project No 1120952 Final Report. 112 Pages.

El Barbri, N., Mirhissea, J., Ionescub, R., El Bari, N., Correig, X., Bouchikhi, B. \& Llobet, E. (2009). An electronic nose system based on a micro machined gas sensor array to assessthe freshness of sardines. Sensors and Actuators B, 141: 538-543.

Escuderos, M.E., Sánches, S. \& Jiménez, A. (2011). Quartz Crysta Microbalance (QCM) sensor arrays selection for olive oil sensory evaluation. Food Chemistry, 124: 857-862.

Fernandez-Diaz, M.D., Montero, P. \& Gomez-Guillen, M.C. (2001). Gel properties of collagens from skins of cod (Gadus morhua) and hake (Merluccius merluccius) and their modify- cation by the coenhancers magnesium sulphate, glycerol and transglutaminase. Food Chemistry, 74: 161-167. doi: 10.1016/S0308-8146(01)00110-8

GME. (2013). All about gelatin, (2013). $<$ http://www.gelatine.org/en/infocenter/publications-downloads/all-aboutgelatin.html>. Accessed 02. 01. 2016

GMAI, (2012), Gelatin manufacturers of Europe < http://www.gelatine.org/en/gelatine /overwiev/127.htm.> (15.01.2016)

Gómez-Guillén, M.C., Turnay,J., Fernández- Diaz, M.D., Ulmo, N., Lizarbe M.A. \& Montero, P. (2002). Structural and physical properties of gelatin extracted from different marine species: A comparative study. Food Hydrocolloids, 16: 25-34. doi: 10.1016/S0268-005X(01)00035-2

Grossman, S. \& Bergman, M., (1992). Process for the production of gelatin from fish skins. U.S. patent 5,093, 474.

Gudmundsson, M. \& Hafsteinsson, H. (1997). Gelatin from cod skins as affected by chemical treatments. Journal of Food Science, 62(1): 37-39. doi: 10.1111/j.1365-2621.1997.tb04363.x

James D., Scott S.M., Ali Z. \& O'Hare W.T. (2005). Chemical sensors for electronic nose systems. Microchimica Acta, 149: 1-17

Jongjareonrak, A., Rawdkuen, S., Chaijan, M., Benjakul, S., Osako, K. \& Tanaka, M. (2010). Chemical compositions and characterisation of skin gelatin from farmed giant catfish (Pangasianodon gigas). LWT Food Science and Technology, 43: 161-165. doi:10.1016/j.Iwt.2009.06.012

Karim, A.A. \& Bhat, R. (2009). Review fish gelatin: properties, challenges, and prospects as an alternative to mammalian gelatins. Food Hydrocolloids, 23: 563-576. doi: 10.1016/j.foodhyd.2008.07.002

Kasankala, L. M., Xue, Y., Weilong, Y., Hong, S. D. \& He, Q. (2007). Optimization of gelatin extraction from grass carp (Catenopharyngodon idella) fish skin by response surface methodology, Bioresource Technology, 98: 3338-3343. doi: 10.1016/j.biortech.2006.03.019

Kent, M., Oehlenschlager, J., Mierke-Klemeyer, S., Manthey-Karl, M., Knochel, R., Daschner, F. \& Schimmer, O.(2004).A new multivariate approach to the problem of fish quality estimation. Food Chemistry, 87: 531-535. doi:10.1016/j.foodchem.2004.01.004

Kim, S.E. \& Mendis, E. (2006). Bioactive compounds from marine processing byproducts. A review. Food Research International, 39: 383-393. doi:10.1016/j.foodres.2005.10.010

Liu, L., Liu, C., Fishman, M.L. \& Hicks, K.B. (2007). Composite films from pectin and fish skin gelatin or soybean flour protein. Journal of Agricultural Food Chemistry, 55: 2349-2355

Morrison, N.A., Clark, R.C., Chen, Y.L., Talashek, T. \& Sworn, G. (1999). Gelatin alternatives for the food industry. Progress in Colloid and Polymer Science, 114: 127-131.

Mumyakmaz, B., Özmen, A., Ebeoğle, M.A. \& Taşaltın, C. (2008). Predicting gas concentrations of ternary gas mixtures for a predefined $3 \mathrm{D}$ sample space. Sensors and Actuators B, 128: 594-602

Muyonga, J.H, Cole, C.G.B. \& Duodu, K.G. (2004). Extraction and physicochemical characterisation of Nile perch (Lates niloticus) skin and bone gelatin. Food Hydrocolloids, 18: 581-592

Ninan, G., Joseph, J. \& Aliyamveettil Z.A., (2014). A comparative study on the physical, chemical and functional properties of carp skin and mammalian gelatins. Journal of Food Science and Technology, 51(9): 2085-2091.

Norland, R.E. (1990). Fish gelatin. In: Advances in fi sheries technology and biotechnology for increased profi tability. Eds Voight, M.N., Botta, J.K. Technical Publication Lancaster, 325-333.

Osborne, R., Voigt, M.N. \& Hall, D.E. (1990). Utilization of lumpfish (Cyclopterus lumpus) carcasses for the production of gelatin. In: Advances in fisheries technology and biotechnology for increased profitability. Eds Eds Voight, M.N., Botta, J.K. Technical Publication Lancaster, 143-153.

Rahman, M.S., Al-Saidi, G.S. \& Guizani, M. (2008). Thermal characterisation of gelatin extracted from yellowfin tuna skin and commercial mammalian gelatin. Food Chemistry, 108: 472-481. doi:10.1016/j.foodchem.2007.10.079

Sae-leaw, T. \& Benjakul, S. (2014). Physico-chemical properties and fishy odour of gelatin from seabass (Lates calcarifer) skin stored in ice. Food Bioscience, 10: 59-68. doi:10.1016/j.fbio.2015.02.002

Saraoğlu, H.M. (2008). Elektronik Burun Teknolojisi ve Uygulama Alanları. Akademik Bilişim Konferansı, January $30^{\text {th }}$ - February $1^{\text {th }}$, Çanakkale, Turkey. Available at: http://ab.org.tr/ab08/kitap/Bildiriler/HMSarao\%F0lu_AB08.pdf.

Shyni, K., Hema, G.S., Ninan, G., Mathew, S., Joshy, C.G. \& Lakshmanan, P.T. (2014). Isolation and characterization of gelatin from the skins of skipjack tuna (Katsuwonus pelamis), dog shark (Scoliodon sorrakowah), and rohu (Labeo rohita). Food Hydrocolloids, 39: 68-76.

Tuik, (2013), Turkish Statistical Institute, Fishery Statistics, Ankara.

Zeng, S., Yan, X., Cao, W., Hong, P., Zhang, C. \& Li, L. (2010). Optimisation of extraction conditions and characteristics of skin gelatin from Nile tilapia (Oreochromis niloticus). International Journal of Food Science and Technology, 45: 1807-1813. doi: 10.1111/j.1365-2621.2010.02332.x

Zhou, P. \& Regenstein, J.M. (2004). Optimization of extraction conditions for pollock skin gelatin. Journal of Food Science, 69(5):393-8. doi: 10.1111/j.1365-2621.2004.tb10704.x 